\title{
Efficiency Analysis of Commuter Line Stations (Case study: Tebet Station to Cilebut Station, Indonesia)
}

\author{
Aisyah Nur Jannah \\ Master Programme in Transport and \\ System Engineering \\ Gadjah Mada University \\ Yogyakarta, Indonesia \\ aisyahnurjannah.anj@gmail.com
}

\author{
Imam Muthohar \\ Master Programme in Transport and \\ System Engineering \\ Gadjah Mada University \\ Yogyakarta, Indonesia \\ i.muthohar76@gmail.com
}

\author{
Danang Parikesit \\ Master Programme in Transport and \\ System Engineering \\ Gadjah Mada University \\ Yogyakarta, Indonesia \\ parikesit.danang@gmail.com
}

\begin{abstract}
Railway transportation is one of the most commonly used to commute by citizen of Jabodetabek (JakartaBogor-Depok-Tangerang-Bekasi). The train station is part of the railroad infrastructure, including the Jabodetabek area which also has a large number of stations. In this case, the station needs its own efficiency assessment. This is because efficiency can lead train transportation to a transportation system that is more efficient and effective. In addition, by knowing the value of efficiency, it also supports the objectives of the National Transportation System (also known as Sistranas) as stated in Minister of Transportation Regulation No. KM 49 in 2005. This study aims to analyze the efficiency of the railway station. with the results-based orientation of the Data Envelopment Analysis (DEA) method and solving the problem of inefficient stations by the projection method. This research was conducted at 15 stations in Jabodetabek (Tebet Station to Cilebut Station). The results showed that $60 \%$ (9 stations) were declared efficient, which was known by evaluating using the CRS (Constant Return to Scale) method and 87\% (13 stations) were also declared efficient by using the VRS (Variable Return to Scale) method. Then priority handling was determined to help the operator handle inefficient variables.
\end{abstract}

Keywords: efficiency, station, railway, DEA

\section{INTRODUCTION}

Commuter Line serves the citizen of Jabodetabek to commute every day. It has many routes reaching BogorDepok, Tangerang, Rangkasbitung and Bekasi-Cikarang. Based on 2017 data, the commuter line has transported $315,853,991$ passengers each year or 886,000 passengers each day with passenger growth of $12.57 \%$ [1]. Following the demand, Jabodetabek already has 79 stations as a transportation node. However, commuter line stations were certainly obtained with a high cost. The construction of the station, the procurement and management of assets in it certainly need to be a concern of many parties so that the management of the train station could support the National Transportation System or Sistranas which states that the national transportation target is to achieve effective and efficient transportation [2]. Based on this mandate, an evaluation of the level of efficiency is needed for commuter line stations so that the mode of transportation of Indonesian railways can be improved. Increased efficiency is expected to be a step to maximize resources and assets at the station to produce maximum output and profit. Improvements to the transportation node do not directly affect the entire Indonesian rail system, but by making improvements to one part of the transportation system could play a role in improving the overall Indonesian rail system. This research will be conducted at 15 commuter line train stations (Tebet Station to Cilebut Station) to determine the efficiency level of each station. In this study, the main function of the station is used as a research boundary. Tebet Station to Cilebut Station is located on the most crowded Jabodetabek commuter line. By knowing the level of efficiency of each commuter line train station and its efficiency improvement solution, a basis for consideration for the Government and operators of commuter line train facilities in giving priority to handling station inefficiencies then can be provided.

\section{LITERATURE REVIEW}

\section{A. Effectivity and Efficiency in Transportation}

Effectiveness and efficiency in the perspective of transportation have been explained in the National Transportation System (Sistranas) which is regulated in Minister of Transportation Regulation No. 49 of 2005. The foal of Sistranas is to achieve effective and efficient transportation. The definition of transportation effectiveness is safe, high accessibility, integrated, sufficient capacity, organized, smooth and fast, easily achieved, on time, comfortable, affordable, and low in pollution. The efficiency of transportation is a low public burden and high utility in a unified national transportation network. Another definition of transportation efficiency is being able to provide maximum benefits with certain sacrifices that must be borne by the government, operators, the community and the environment, or providing certain benefits with minimum sacrifice. Efficiency can be measured based on the comparison of benefits with the total costs incurred. Utilization referred to in Sistranas is the level of capacity utilization of the transportation system that can be expressed by indicators such as passenger load factor, load factor and the level of use of facilities and infrastructure [2].

\section{B. Railway Station as a Transportation Node}

Minister of Transportation Regulation No. 49/2005 defines a transportation node as a place to pick up or drop off passengers, unload and load goods, arrange travel and intra mode or inter modal transfer sites. The train station is one of 
the railroad infrastructures in addition to the railway line and railroad operations facilities. Based on Law No. 23/2007, a station is a place where trains depart or stop to pick up or drop off passengers, load and unload goods, and / or activities carried out for the purposes of railroad operations [3].

The International Union of Railways or The UIC conceptualizes smart stations as supporting smart cities. The concept of smart stations makes the role of stations in the present and the future not only a social space, but can also play a role in business processes. There are 3 (three) pillars in the concept of smart stations, namely smart management, smart infrastructure, and smart mobility [4]. Smart management is the need for station managers to do new things that can improve the process of using information and communication technology. Smart infrastructure is to add value by enhancing features through new designs or the use of the latest technology, while smart mobility is the use of technology to facilitate passengers in providing information about time and place. UIC also stated that in the future, the community will not only consider the station as a place to be traversed, but the station will have another function as a place to transport modes in multimodal travel so good management is needed in managing waiting times [4].

\section{Efficiency of Transportation Research}

Many studies used the Data Envelopment Analysis (DEA) method as a method of measuring non-parametric efficiency because a non-parametric approach is an approach whose model does not require certain conditions such as population parameters of the study sample; simple; and easy to use because it does not require a lot of function form specifications (so that the formation errors are smaller) [5]. Research using the DEA method to obtain the level of efficiency in the field of transportation has been widely carried out abroad. G. Georgiadis, I. Politis, and P. Papaioannou, has conducted research on the measurement and improvement of efficiency and effectiveness of the public bus transportation system in Greece [6]; Marchetti and Wanke have conducted research related to the analysis of the efficiency of cargo train transportation in Brazil [7]; Rashidi and Cullinane evaluated the performance of sustainable national logistics for 22 countries from the Organization for Economic Cooperation and Development (OECD) [8].

The Data Envelopment Analysis (DEA) method has also been used in measuring the efficiency of transportation nodes. Research has been carried out mainly at ports and airports. Barros and Dieke have conducted a literature study of studies using Data Envelopment Analysis (DEA) at the airport and summarizing the input and output variables used in previous studies [9]. Literature study was conducted in 5 studies in 1997-2001. S. Lozano, G. Villa, and D. Canca conducted a literature study related to the use of the Data Envelopment Analysis (DEA) method at the port [10]. Literature studies were conducted in 9 studies in 2001-2006. Research related to efficiency at train station has been conducted by several researchers, although not as much as research at airports and ports. M. K. Sameni, J. Preston, and M. K. Sameni. conducted a study of the efficiency levels of train stations in the UK [11]. Terminal studies have also been carried out by L. Sun, J. Rong, and L. Yao for 10 terminals in Beijing [12].

\section{Methodology}

\section{A. Research Location}

The study was conducted at 15 commuter line stations from Tebet Station to Cilebut Station. Data collection in this study was conducted in March 2019. The location of the study can be seen in Fig. 1.

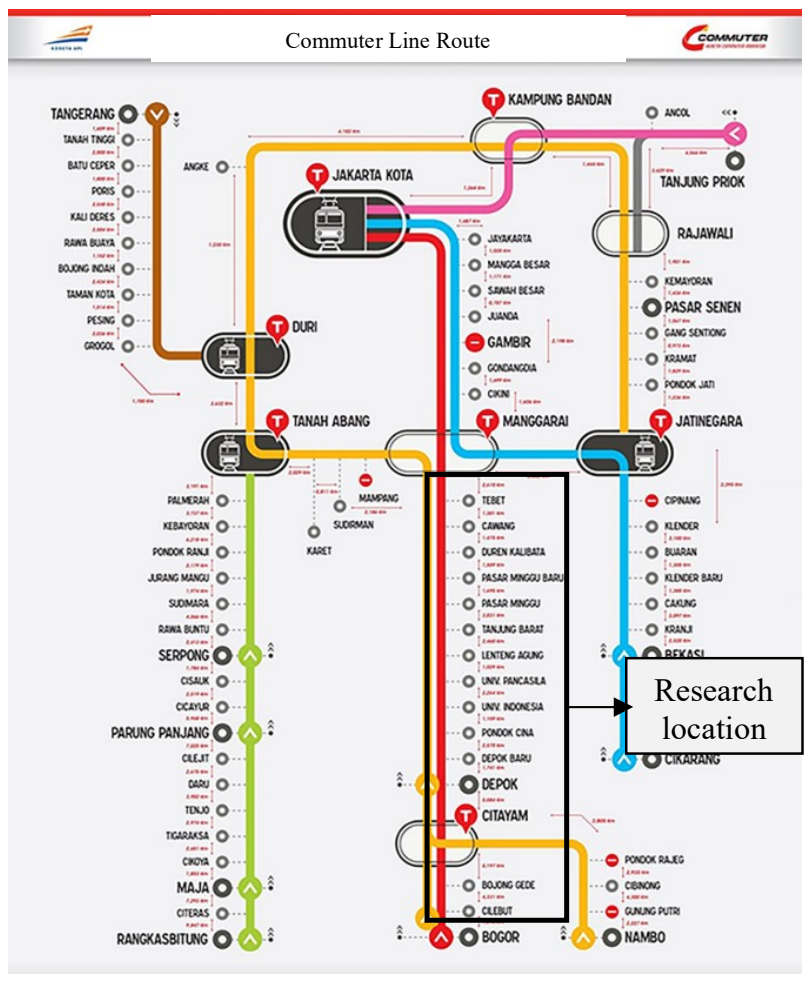

Fig. 1. Location of the research.

\section{B. Input and Output Variabels}

Determination of input and output variables was done by literature study and observation. Literature studies were carried out in journals and previous regulations relating to stations in Indonesia. Observations were made at several stations to determine the condition and activities of the station that occurred at the station. Input variables are the number of electronic gates, the number of ticket sales services (manual counters or Commuter Vending Machines), the number of ATMs, the number of businesses, the platform area, and the number of employees while the output variable is the Number of Passengers.

\section{Data Envelopment Analysis (DEA)}

Productivity and efficiency have a strong enough relationship. According to T. J. Coelli, D. P. Rao, G. E Battese, and C. J. O'Donell, before understanding the meaning of efficiency, it is very necessary to first understand the meaning of productivity. The productivity of an organization is the ratio or comparison between the output produced and the inputs used [13]. They state that understanding the relationship between productivity and efficiency also means that it is needed to understand the existence of frontier production functions [13]. The frontier production function is a function that connects the input and 
output of a productivity which represents the maximum output that can be produced by the input. If an organization operates in the frontier production function, it can be said that the organization is technically efficient.

T. J. Coelli, D. P. Rao, G. E Battese, and C. J. O'Donell stated that Data Envelopment Analysis (DEA) was the first method introduced by Charnes, Cooper, and Rhodes in 1978 and 1979 [13]. The DEA method emphasizes task-oriented efficiency analysis and focuses on evaluating the performance of the Decision Making Unit (DMU) which results in an efficiency value relative to a comparable DMU [14]. DMU is a unit that will conduct efficiency analysis. The frontier line is formed based on DMUs that are considered efficient. DMU that is on the frontier line is considered as an efficient DMU relative to other DMUs in the peer group. In addition to its relative efficiency value, DEA can also indicate units that are references for inefficient units. Banker, Charnes, and Cooper developed the VRS method in 1984 so this model is often referred to as the BCC model [14]. This model assumes that the analyzed DMU has not operated at an optimal scale or in other words the ratio between the increasing input values and the increasing output values is not the same. Increasing the input value by $\mathrm{x}$ times will not increase the value of output $x$ as well, but the increase can be greater or smaller than the value of $x$. DMUs that are not at an optimal scale are caused by imperfect competition, government regulations, financial constraints, etc. [14]. Output-oriented measurement is the opposite of input-oriented measurement where the unit will be efficient if the inefficient unit can increase the number of outputs with the same input [15].

Data envelopment analysis (DEA) is used to measure the level of efficiency from Tebet Station to Cilebut Station. The methods used were the CRS (Constant Return to Scale) and VRS (Variable Return to Scale) methods and the orientation used is the output orientation. This analysis used Win4DEAP 2.1 software.

\section{RESULTS}

\section{A. Level of Efficiency}

The level of efficiency of a commuter line train station will be measured by several input variables and output variable. The input variables included are the number of electronic gates, number of ticket sales services, number of ATMs, number of businesses, platform area, and number of employees. The output variable used in calculating this efficiency level is the passenger volume. The results of measuring the level of efficiency using the Data Envelopment Analysis (DEA) method with output based orientation can be seen in Fig. 2 and the results of the efficiency calculations of 15 review stations are summarized in TABLE I.

Based on TABLE I, efficiency measurements using the CRS (Constant Return to Scale) method show that $60 \%$ (9 stations) are declared efficient and 40\% (6 stations) are declared inefficient. Whereas measurements using the VRS (Variable Return to Scale) method show that 87\% (13 stations) are efficient and 13\% (2 stations) are inefficient. The number of stations that have been very efficient at pure technical efficiency (PTE is calculated using the VRS method) is greater than that of stations that have been perfectly efficient at technical efficiency (TE is calculated using the CRS method). This is because VRS calculations add constraints that indicate the actual condition of the station under study. The VRS calculation assumes that in its implementation, the station has not been able to scale optimally due to other factors such as those caused by imperfect competition, government regulations, financial constraints, and others.

TABLE I. Summary OF Stations EFFiciency

\begin{tabular}{|c|c|c|c|c|}
\hline \multirow[b]{2}{*}{ Parameters } & \multicolumn{2}{|c|}{ CRS } & \multicolumn{2}{|c|}{ VRS } \\
\hline & $\begin{array}{c}\text { Amount of } \\
\text { station }\end{array}$ & Percentage & $\begin{array}{c}\text { Amount } \\
\text { of } \\
\text { station }\end{array}$ & Percentage \\
\hline $\begin{array}{l}\text { Efficient } \\
\text { Stations }\end{array}$ & 9 & $60 \%$ & 13 & $87 \%$ \\
\hline $\begin{array}{l}\text { Inefficient } \\
\text { Stations }\end{array}$ & 6 & $40 \%$ & 2 & $13 \%$ \\
\hline Total & 15 & $100 \%$ & 15 & $100 \%$ \\
\hline $\begin{array}{l}\text { Average of } \\
\text { Efficiency } \\
\text { Level }\end{array}$ & \multicolumn{2}{|l|}{0.915} & \multicolumn{2}{|l|}{0.991} \\
\hline
\end{tabular}

1.2

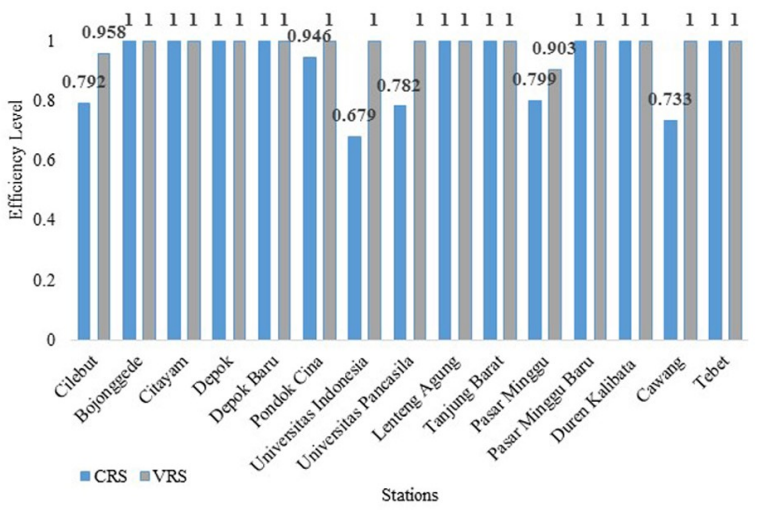

Fig. 2. Efficiency level of Tebet Station - Cilebut Station.

\section{B. Increasing Efficiency of Commuter Line Station}

The method used to increase the efficiency of stations that are still inefficient was the projection value method. Projection value is the value of input and output variables that should be used so that the station can have perfect efficiency. Projection values are obtained by adding or subtracting values from existing variables. The difference in the value of the projection with the value of existing variables can be negative, zero, or positive. In the input variable, the difference in value is between negative and zero. So, to achieve optimal efficiency, there are two choices, namely the value of existing variables must be reduced or not. In the output variable, the difference in value is between zero and positive. So, to achieve optimal efficiency, there are two choices, the value of existing variables must be added or not. Fig. 3 and Fig. 4 will show the percentage of inefficiencies that occur at each station and each variable based on the CRS and VRS methods. 


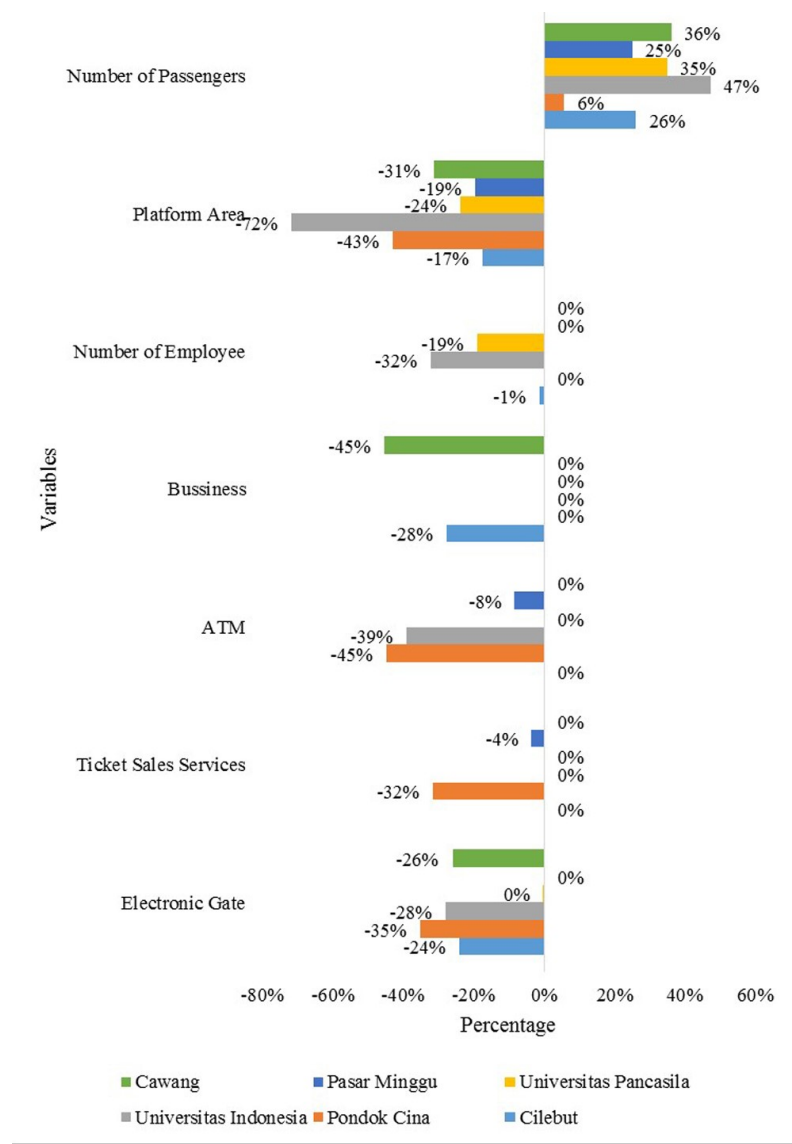

Fig. 3. The percentage of inefficiencies each station (CRS method).

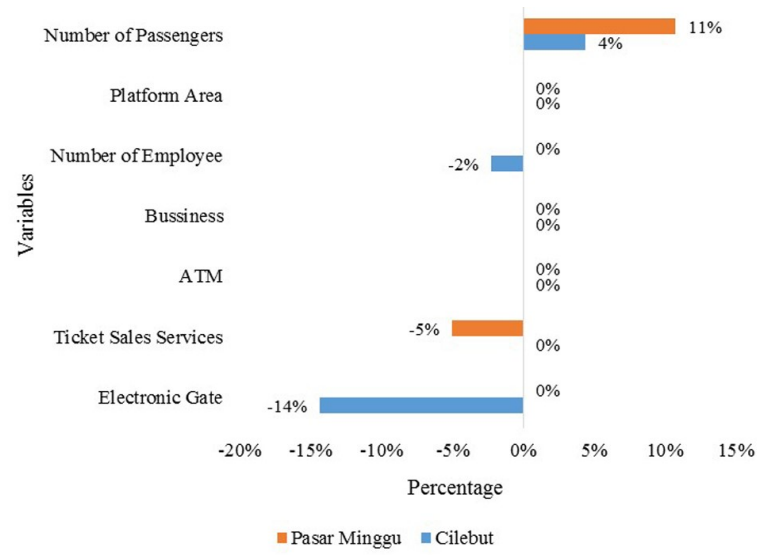

Fig. 4. The percentage of inefficiencies each station (VRS method).

\section{Variable Priority Handling}

The handling of inefficiencies was actually not easy to do, considering the assets that available at the review station are quite difficult if a reduction is made. This is because the installed assets will require costs of uninstalling and transportation. However, if it is possible to dismantle electronic gates and Commuter Line Vending Machines, then these assets can be transferred to other stations that need these assets more such as new stations or stations which still lack of assets. Reducing manual counters can be done by deactivating the manual window. Reduction of ATMs and businesses can be done by limiting the number of ATMs and businesses available at the station and transferring the function of the room. The inefficient platform cannot be dismantled, but the platform can be converted into another space. The number of inefficient employees can be transferred to other stations. Inefficient passenger volume, in this case there are targets that must be fulfilled by the station in order to increase efficiency. It can be done by making a transportation policy that can make people switch modes to commuter line train transportation modes. Each station has priority in handling different inefficiencies both in terms of technical efficiency (CRS method) or pure technical efficiency (VRS method). Handling priorities can be used by each station to carry out management of the handling funding. The consideration of handling priorities was based on the percentage difference only as limitation. The greater percentage difference between the existing value and the projection value is the more priority to handle. Handling priority of each station using the CRS and VRS methods can be seen in TABLE II.

TABLE II. HANDLING PrioRity OF EACH Station

\begin{tabular}{|l|l|l|}
\hline \multicolumn{1}{|c|}{ Stastion } & \multicolumn{1}{c|}{$\begin{array}{c}\text { Priority Handling } \\
\text { Variable (CRS) }\end{array}$} & $\begin{array}{l}\text { Priority Handling } \\
\text { Variable (VRS) }\end{array}$ \\
\hline \multicolumn{1}{|c|}{ Cilebut } & \multicolumn{1}{|c|}{ Business } & \multicolumn{1}{c|}{ Electronic gate } \\
\hline Pondok Cina & ATM & - \\
\hline Universitas Indonesia & Platform area & - \\
\hline Universitas Pancasila & Number of Passenger & - \\
\hline Pasar Minggu Baru & Number of Passenger & $\begin{array}{l}\text { Number of } \\
\text { Passenger }\end{array}$ \\
\hline Cawang & Business & - \\
\hline
\end{tabular}

\section{CONCLUSIONS}

Efficiency measurements using the CRS (Constant Return to Scale) method show that $60 \%$ ( 9 stations) are declared efficient and 40\% (6 stations) are declared inefficient. Whereas measurements using the VRS (Variable Return to Scale) method show that $87 \%$ (13 stations) are efficient and $13 \%$ (2 stations) are inefficient. Station inefficiency handling priorities using the projected values on the CRS method should be carried out in the platform area at Universitas Indonesia Station $-72 \%$, passenger volume at Universitas Indonesia Station is $47 \%$, the number of ATMs at Pondok Cina Station and $-45 \%$ for Cawang Station. Station inefficiency handling priorities using projection values in the VRS method should be carried out on the number of electronic gates at Cilebut Station by $-14 \%$, passenger volumes at Pasar Minggu Station by $11 \%$, and ticket sales services by $-5 \%$.

\section{REFERENCES}

[1] PT. Kereta Commuter Indonesia, Annual Report, Jakarta: PT. KCI, 2017.

[2] Ministry of Transportation, Regulation of the Minister of Transportation Number KM 49 of 2005 concerning the National Transportation System (in Indonesian), Jakarta: Ministry of Transportation, 2005.

[3] Republic of Indonesia, Law Number 23 of 2007 concerning Railways (in Indonesian). Jakarta: Republic of Indonesia, 2007.

[4] International Union of Railways, Smart Stations in Smart Cities. Paris: International Union of Railways, 2017. 
[5] A. S. Rusydiana, Measuring the Efficiency Level with Data Envelopment Analysis (in Indonesian), Bogor: Tim Smart Consulting, 2013.

[6] G. Georgiadis, I. Politis, and P. Papaioannou, Measuring and improving the efficiency and effectiveness of bus public transport systems, RTE, vol. 48, pp. 84-91, 2014.

[7] D. Marchetti and P. Wanke, Brazil's rail freight transport: Efficiency analysis using two-stage DEA and cluster-driven public policies, Socio-Econ Plan Sc, vol. 59, pp. 26-42, 2017.

[8] K. Rashidi and K. Cullinane, K., Evaluating the Sustainability of National Logistics Performance Using Data Envelopment Analysis, Transport Policy, vol. 74, pp. 35-46, 2019.

[9] C. P. Barros, P. U. Dieke, Performance evaluation of Italian airports: A data envelopment analysis, JATM, vol. 13, pp. 184-191, 2007.

[10] S. Lozano, G. Villa, D. Canca, Application of centralised DEA approach to capital budgeting in Spanish ports, Comput Ind Eng, vol. 60(3), pp. 455-465, 2011.

[11] M. K. Sameni, J. Preston, M. K. Sameni, Evaluating Efficiency of Passenger Railway Stations: A DEA Approach, RTBM, vol. 20, pp. 33-38, 2016.

[12] L. Sun, J. Rong, and L. Yao, Measuring Transfer Efficiency of Urban Public Transportation Terminals by Data Envelopment Analysis, J Urban Plan D-Asce, vol. 136(4), pp. 314-319, 2010.

[13] A. Charnes, W. W. Cooper, A.Y. Lewin, L. M. Seiford, Data envelopment analysis: Theory, methodology, and applications. New York: Springer Science \& Business Media, 1994.

[14] T. J. Coelli, D. P. Rao, G. E Battese, C. J. O'Donell, An Introduction to Efficiency and Productivity Analysis 2nd ed. New York: Springer Science \& Business Media, 2005.

[15] A. S. Rusydiana, Measuring the Efficiency Level with Data Envelopment Analysis (in Indonesian), Bogor: Tim Smart Consulting, 2013. 